\title{
Climate change and conservation of endemic amphidromous fishes in Hawaiian streams
}

\author{
R. P. Walter ${ }^{1,2,4, *}$, J. D. Hogan ${ }^{3}$, M. J. Blum ${ }^{2}$, R. B. Gagne ${ }^{2}$, E. F. Hain ${ }^{1}$, J. F. Gilliam ${ }^{1}$, \\ P. B. McIntyre ${ }^{3}$ \\ ${ }^{1}$ Department of Biology, North Carolina State University, Raleigh, North Carolina 27695-7617, USA \\ ${ }^{2}$ Department of Ecology and Evolutionary Biology, Tulane University, New Orleans, Louisiana 70118, USA \\ ${ }^{3}$ Center for Limnology, University of Wisconsin, Madison, Wisconsin 53706-1413, USA \\ ${ }^{4}$ Present address: Great Lakes Institute for Evironmental Research, University of Windsor, \\ Windsor, Ontario, Canada N9B 3P4
}

\begin{abstract}
Amphidromous fishes are important members of oceanic island freshwater communities. Although often depauperate, amphidromous fish assemblages on islands are largely composed of endemic species. Little is known about the effects of anthropogenic stressors on amphidromous fishes, and the consequences of climate-driven changes in water quality and quantity are particularly uncertain. Focusing on native fishes in Hawaii, we discuss the potential for climate change to intensify 3 major threats facing amphidromous fish: (1) loss of 'ridge-to-reef' migratory corridors via disruption of surface water connectivity, (2) in-stream habitat degradation and (3) exotic species introductions. Successfully addressing these and other threats to native fish in Hawaii will require approaches that balance conservation needs with use of water resources. Conservation initiatives should focus on 'scaling up' ongoing projects intended to demonstrate how stream protection and restoration, non-native species removal and reintroductions can benefit at-risk species. Research initiatives should focus on determining the ecological controls on recruitment under current and future climate conditions.
\end{abstract}

KEY WORDS: Amphidromy · Climate change · Freshwater fishes · Hawaii · Ocean-stream connectivity Resale or republication not permitted without written consent of the publisher

\section{INTRODUCTION}

Conservation of diadromous fishes has largely focused on imperiled anadromous species that support economically important fisheries. In comparison, little attention has been paid to amphidromous fishes, including endemic species of cultural importance. Little is known about the effects of anthropogenic stressors on amphidromous fishes, including climate-driven changes in water quality and quantity, which can potentially result in catastrophic losses by disrupting crucial dispersal pathways, intensifying habitat degradation and promoting the spread of invasive species.

Amphidromous species are often the predominant native fishes of naturally depauperate freshwater communities on oceanic islands. Low species diver- sity on oceanic islands reflects the geographical isolation and oceanic dispersive origins of resident freshwater fauna (McDowall 2010). Both factors also contribute to high levels of endemicity (Watson 1991, McDowall 2003, Lord et al. 2010). The Hawaiian Islands, for example, host 5 endemic amphidromous species from 5 different genera (McDowall 2003, Lindstrom et al. in press). As the predominant members, and in some cases the sole constituents, of freshwater fish assemblages on tropical and subtropical oceanic islands (Radtke \& Kinzie 1996), amphidromous species represent important contributions to global freshwater biodiversity (McDowall 2004). Consequently, conservation of amphidromous fishes is crucial for sustaining unique freshwater fish assemblages on islands worldwide. 
Amphidromy can enhance metapopulation resilience by enabling colonization, recolonization and rescue of local populations across a network of watersheds within and among islands (McDowall 2010, Keith et al. 2011), but it also presents a distinctive set of biotic and abiotic conditions that place species at risk. Amphidromy is a tri-phasic life history in which ontogeny occurs in both freshwater and marine environments. It has 6 fundamental characteristics (following McDowall 2010): (1) spawning, egg development and hatching of larvae occur in freshwater; (2) larval dispersal occurs via downstream transport to the sea; (3) larvae develop at sea for a period of a few weeks to a few months; (4) postlarval individuals and/or juveniles return to freshwater; (5) juveniles and/or adults feed and develop in a riverine ecosystem; and (6) adults mature and spawn in a riverine system. Amphidromous fauna, therefore, are exposed to threats that unfold across 3 separate demographic stages: larval populations pass through an oceanic dispersing phase subject to shifting currents driven by weather and climate conditions; recruiting post-larval populations must locate and navigate freshwater outflows, which can involve inland migration from estuaries to headwater reaches; and adult populations experience in-stream biotic and abiotic stressors arising from contaminants (Sutherland 2000, Brasher \& Wolff 2004), habitat degradation and introduced exotic species. Mortality bottlenecks can occur at any or all of these stages (Murphy \& Cowen 2007).

Identifying how individual and multiple stressors place amphidromous species at risk can promote more effective conservation. Focusing on species endemic to Hawaiian streams, we summarize threats faced by amphidromous fishes during different life history stages, placing emphasis on how changing climate conditions can increase the likelihood of local population decline and global extinction. Hawaiian species are among the best studied assemblages of amphidromous fishes. Building on this understanding, we examine how well-recognized threats may be exacerbated by emerging climate stressors common to islands and archipelagos across the world.

\section{HAWAII ‘ $\mathrm{O}^{\prime} \mathrm{OPU}$}

Like many other insular freshwater assemblages, Hawaiian amphidromous fishes exhibit high levels of endemism. Referred to as 'o'opu in Hawaiian, the assemblage consists of 5 gobioid fishes: 4 gobies (Awaous guamensis, Lentipes concolor, Stenogobius hawaiiensis and Sicyopterus stimpsoni; Gobiidae) and one sleeper (Eleotris sandwicensis; Eleotridae). All occur only on islands with perennial streams (Hawaii, Maui, Molokai, Oahu and Kauai). With the exception of $A$. guamensis, 'o'opu are currently recognized as being endemic to Hawaii. Recent genetic analyses, however, indicate that $A$. guamensis in Hawaii constitute a distinct evolutionary lineage from populations elsewhere in the Indo-Pacific. Accordingly, Lindstrom et al. (in press) have proposed that Hawaiian populations be recognized as a distinct species, and therefore again be referred to as A. stamineus.

As a general rule, the occurrence of major waterfalls determines the longitudinal distribution of 'o'opu along a river or stream (Keith 2003), such that habitat use and specializations reflect climbing and clinging ability (Fig. 1). Species with poorer climbing abilities (Eleotris sandwicensis and Stenogobius hawaiiensis) are restricted to estuaries and lower stream reaches below the first waterfall (Corkum 2002). Species with strong climbing abilities can


Fig. 1. Awaous guamensis. (A) In-stream and (B) ventral views of A. guamensis. Inset: disc-shaped fused pelvic fin used for ascension of rapids waterfalls 
achieve high elevations. Awaous guamensis and Sicyopterus stimpsoni have the broadest in-stream distributions, with adults and juveniles found in all stream reaches except those above waterfalls exceeding $30 \mathrm{~m}$ (Fitzsimons et al. 2007). Lentipes concolor is known for the ability to ascend the tallest waterfalls in Hawaii (Englund \& Filbert 1997), and is the most common 'o'opu in headwater habitats.

All 'o'opu are threatened by intensifying land use, invasive species and climate change, although different life history traits, such as the length of larval duration (LLD) and within-stream distributions, give rise to different exposure vulnerabilities (MacKenzie 2008, Golbuu et al. 2011). Species with poor climbing ability (Eleotris sandwicensis and Stenogobius hawaiiensis), for example, face threats that primarily target lower stream reaches such as coastal urbanization and the introduction of predators (e.g. tilapia; Oreochromis spp.) into estuaries (Jenkins et al. 2009). Headwater-bound species (e.g. Lentipes concolor and Sicyopterus stimpsoni) are exposed to threats across all stream reaches, and may be more vulnerable to in-stream habitat alteration and the disruption of migratory pathways. Increasing acidification and warming of coastal marine waters may constitute greater threats to species with longer LLD, although both conditions may affect all species by disrupting migratory ability and dispersal pathways within and among islands.

\section{DISRUPTION OF CRITICAL DISPERSAL PATHWAYS}

\section{Ocean-stream connectivity}

Keith (2003) identified 2 factors that are critical for the survival of amphidromous species: (1) a larval pool for recruitment into streams and (2) contributions to the larval pool from each local population of adults. Both of these factors depend on dispersal via ocean-stream connectivity. Completion of the amphidromous life cycle requires migration from freshwater to the marine environment and back again; therefore, 'o'opu and other amphidromous fishes rely on surface water connectivity to move between spawning habitats in streams and larval habitats in the ocean. The marine larval period, which is obligate for most amphidromous species - the exception being some eleotrids (McKaye et al. 1979, Erdman et al. 1984, Michel et al. 2008) - highlights the importance of a 'ridge-to-reef corridor' for species survival (Fitzsimons et al. 1997, McDowall 1997, Radtke et al.
2001, Keith 2003). Reduced or disrupted surface flow of streams and rivers represents one of the greatest threats to 'o'opu population viability (Holmquist et al. 1998). Loss of connectivity disrupts contributions to the marine larval pool and post-larval recruitment to freshwater, while also reducing stream habitat required for reproduction (Holmquist et al. 1998, Benstead et al. 1999, Iida et al. 2010).

Sources of freshwater are limited on islands. Although human populations rely heavily on subsurface freshwater lenses, surface flow in streams is also an important source of freshwater. Wholesale diversion of streams (Fig. 2) and extraction of stream water for residential and economic development are among the primary threats to surface water connectivity on islands. In the Hawaiian archipelago, a $600 \%$ increase in the resident human population over the past 100 yr (US Census Bureau 2010) has led to increased demand for water resources to sustain agricultural and urban development. Hawaiian streams have been diverted (Fig. 2) to serve as water sources for cities, resorts and agricultural operations (Brasher 2003). Surface flow has been altered in at least $58 \%$ of the 366 perennial streams in Hawaii (Parrish et al.

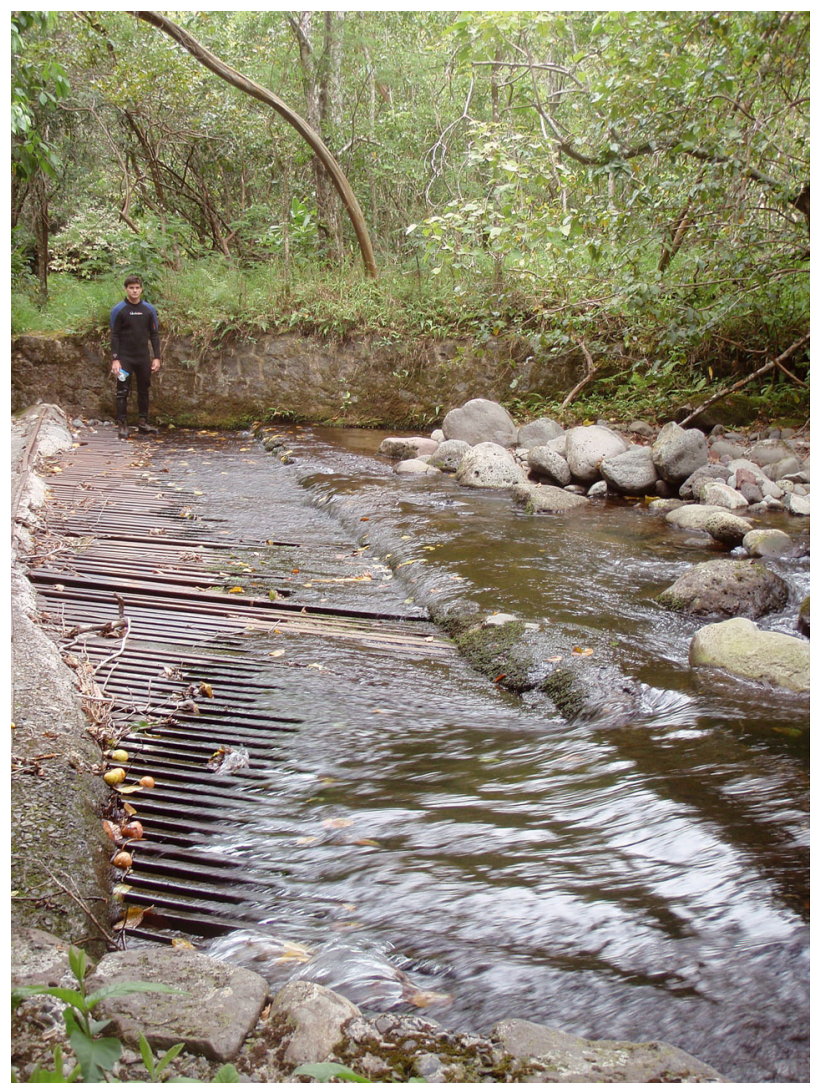

Fig. 2. Water capture at a diversion inlet in upper Waihee Stream, Maui, Hawaii 
1978, Brasher 2003). Although the total amount of surface water being diverted in each watershed varies, stream diversions can reduce total stream flow by capturing a significant portion of base flow (Gingerich \& Wolff 2005).

Water extraction and diversions can substantially alter the longitudinal distribution of 'o'opu by changing the availability of in-stream habitat and by disrupting surface water connectivity (Brasher 1996, 1997, 2003, Gingerich \& Wolff 2005). Disruption of surface water connectivity may reduce or altogether eliminate freshwater flow into coastal marine environments, removing potential recruitment cues (Delacroix \& Champeau, 1992). The attraction of post-larvae to stream mouths following heavy rains (particularly intermittent streams) suggests that freshwater flow may trigger migration inland of larval marine gobies (Delacroix \& Champeau, 1992).

A comparison of 5 watersheds in east Maui showed that base flow capture reduced fish habitat by 46 to $100 \%$ in reaches below diversions without significant groundwater input (i.e. from springs). However, diversions also reduced median water velocity in remaining habitat (Gingerich \& Wolff 2005), which can change occupancy by 'o'opu because species exhibit preferences for different substrate and flow conditions (Kinzie et al. 1984, 1986, Kinzie 1988, Brasher 1997, McRae 2001, Parham 2002). Comparison of a diverted watershed with an undiverted watershed on Molokai showed, for example, that lower densities of native fishes and greater overlap in use corresponded to the reduction and modification of habitat (Brasher 1997). Fewer fish have also been found above diversions, particularly those that result in periodic desiccation of stream reaches (Brasher 1996, 1997). This is likely a result of disrupted upstream migration and entrainment of emigrating larvae (Benstead et al. 1999).

In addition to reduction of surface flow from diversions, streams across Hawaii have experienced a steady decline in base flow since the beginning of the 20th century. Long-term patterns of decline in part correspond to shifts in the dominant plant species in high-elevation forests (Takahashi et al. 2011). Comparisons between native forests and those dominated by invasive strawberry guava (Psidium cattleianum), for example, demonstrated that guava-dominated forests receive significantly less cloud water. Guavadominated forests also have half the canopy water storage capacity of native forests (Takahashi et al. 2011). All of these conditions can result in lower groundwater recharge and less stream channel discharge (Takahashi et al. 2011).
Climate change is expected to directly affect both of the key atmospheric sources of water that support surface flow in oceanic island streams: rainfall and cloudwater deposition (Oki 2004). Regional forecasts remain uncertain, but water balance models driven by precipitation, soil moisture and potential evapotranspiration indicate that reductions in surface flow are likely and that seasonal shifts in surface flow will be more severe than changes in total annual runoff (Lettenmaier \& Gan 1990, Carpenter et al. 1992, Meisner \& Shuter 1992). At tropical latitudes, large oceanic storms supply precipitation that drives wet season flows, whereas cloudwater inputs from trade winds supply as much as $70 \%$ of surface flows during the dry season (Guswa et al. 2007, McJannet et al. 2007). Regional climate models (Timm \& Diaz 2009) predict that wet season precipitation will decrease by 5 to $10 \%$, and that dry season precipitation will increase by $5 \%$. Historical records show that annual precipitation has declined by $15 \%$ over the last $20 \mathrm{yr}$ (Chu \& Chen 2005, Diaz et al. 2005). A doubling of atmospheric $\mathrm{CO}_{2}$ also is expected to result in cloud layers rising several hundred meters (Still et al. 1999). Therefore, fewer clouds will be intercepted at high elevations within oceanic island watersheds, leading to further reductions in groundwater recharge and surface water flows. These predictions are consistent with evidence from long-term monitoring programs (Oki 2004), which indicate that surface flow in streams has been declining (Fig. 3).

\section{The obligate marine larval period}

The marine larval period provides a mechanism by which amphidromous fishes can maintain connectivity among island populations, colonize new habitats and achieve broad geographic ranges (McDowall 2003). However, marine coastal environments are facing an increasing number and magnitude of threats from urbanization (Puritz \& Toonen 2011) and global climate change (Hoegh-Guldberg \& Bruno 2010). Particularly important to amphidromous fishes are physical and chemical changes within the marine environment that may affect larval development and longevity, as well as the ability to avoid predators and locate sources of fresh water.

The dispersal of marine larvae is generally thought to be mediated by ocean currents and modified by organismal behavior such as vertical migration in the water column and sensory ability (Cowen et al. 2006). It is becoming clear that anthropogenic factors can also influence larval dispersal, especially in 
Wailua, Kauai

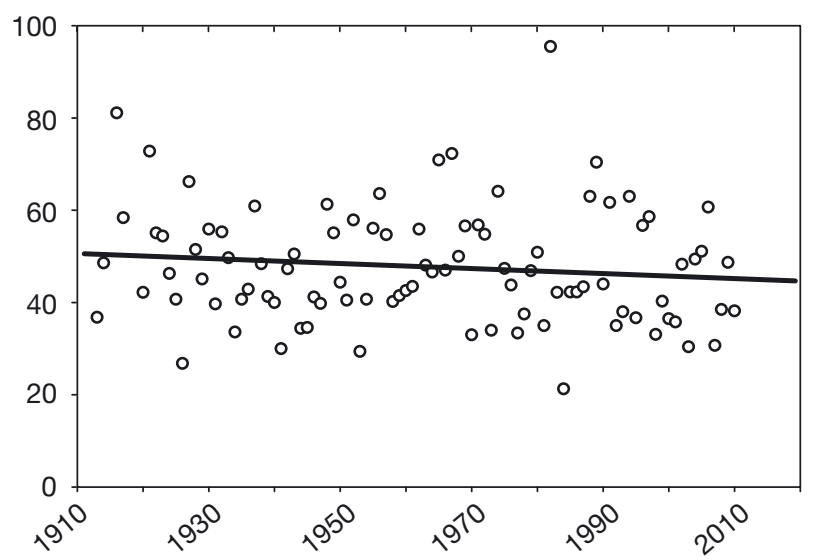

Kalihi, Oahu

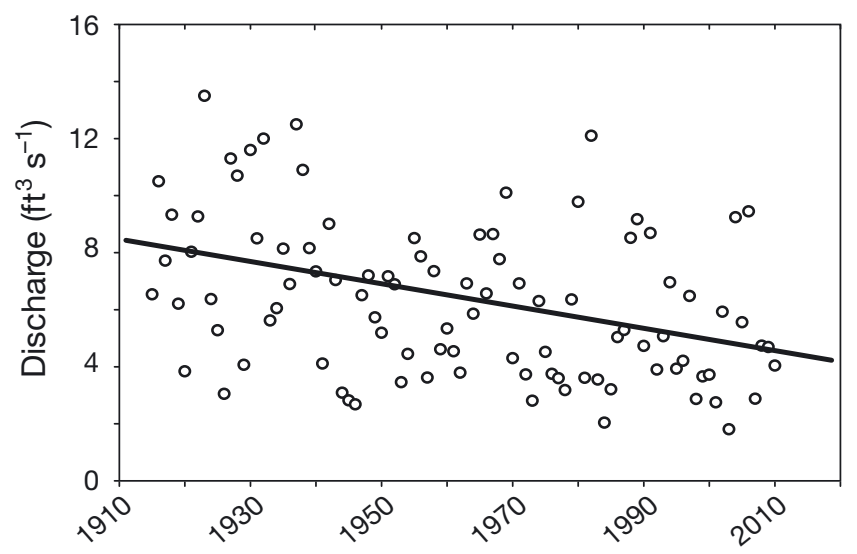

Halawa, Molokai

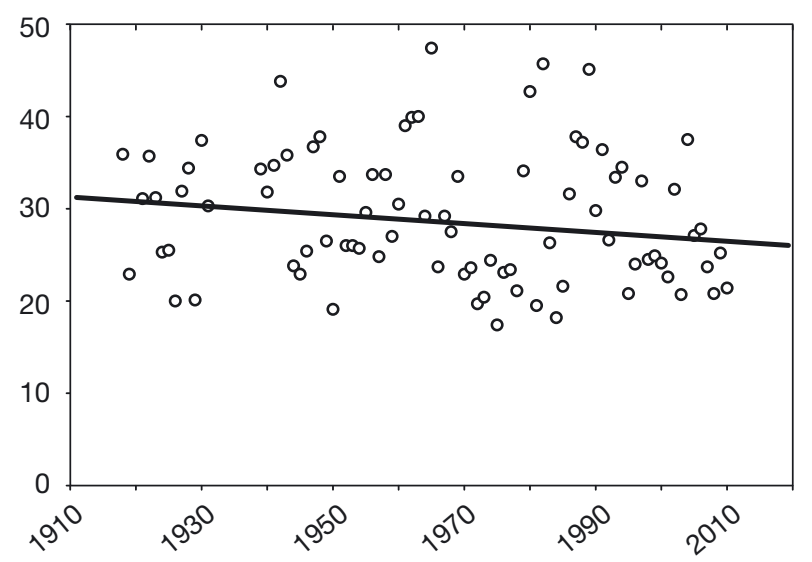

coastal waters. Urbanization and coastal development can result in run-off contaminated with heavy metals, chlorinated hydrocarbons, petrochemicals, nutrients and bacteria that are known to be toxic to marine larvae (Bailey et al. 1995). By diminishing sur-
Wailuaiki, Maui

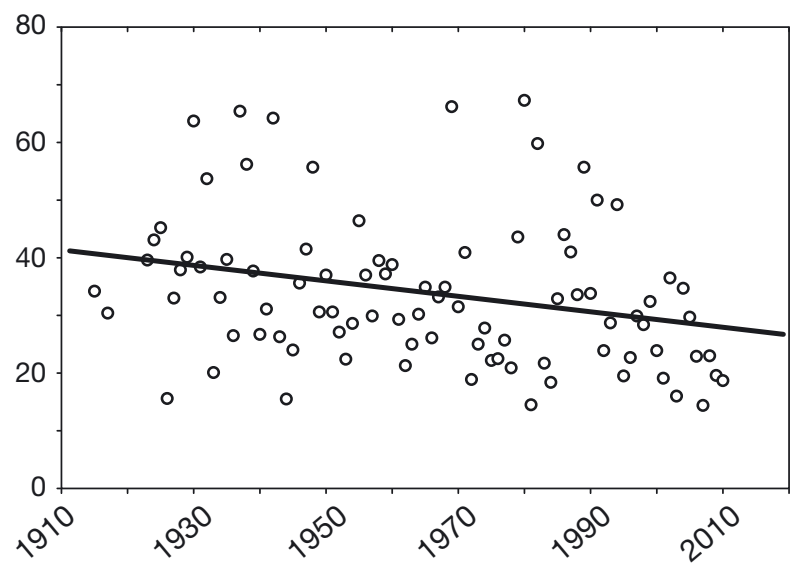

Honolii, Hawaii

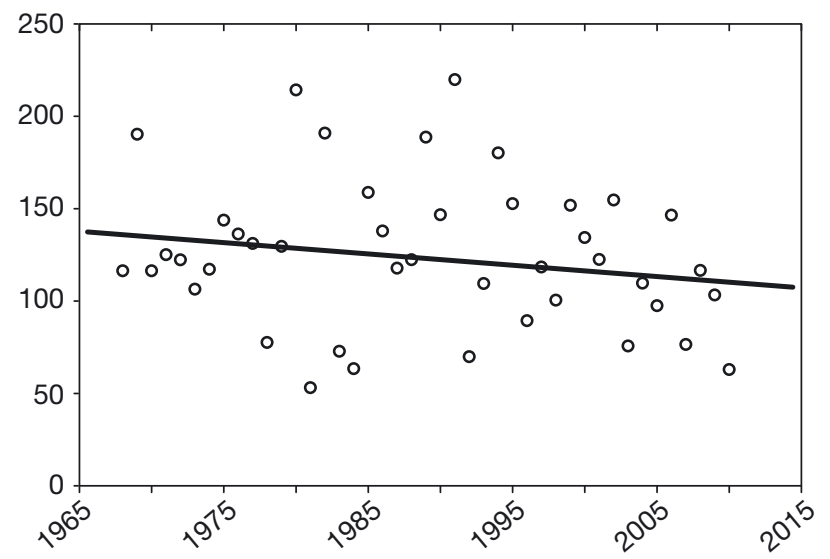

Fig. 3. Examples of declines in stream flow across 5 watersheds in the Hawaiian Islands. Data are from the US Geological Survey (USGS; http://nwis.waterdata.usgs.gov/hi/nwis/ current/?type=flow\&group_key=country_cd) (Oki 2004). Note different years for Honolii. $1 \mathrm{ft}^{3} \mathrm{~s}^{-1}=0.028 \mathrm{~m}^{3} \mathrm{~s}^{-1}$

vival of marine larvae, coastal contamination may create dispersal barriers that impede exchange of recruits among stream populations. Consistent with this idea, Puritz \& Toonen (2011) found that genetic diversity and population connectivity within common 
bat star Patiria miniata populations off the Southern California Bight are depressed in areas subject to contaminant exposure. Although little is known about the relationship between coastal development and marine larval dispersal across the Hawaiian archipelago, contaminants in coastal waters are an emerging concern, especially on islands experiencing rapid urbanization, such as Oahu (Sutherland 2000, Brasher \& Wolff 2004).

Rising ocean temperatures and ocean acidification are among the predicted effects of global climate change that have the potential to alter existing larval recruitment and connectivity patterns through increased larval mortality and shorter larval duration (Sponaugle \& Pinkard 2004, Sponaugle et al. 2006, Munday et al. 2009a). Rising temperatures will enhance energy demands for metabolism (Johansen \& Jones 2011), and ocean acidification may give rise to complicated physiological and behavioral changes in marine fish and larval 'o'opu in oceanic environments. Marine fish (Amphiprion percula) experiencing reduced $\mathrm{pH}$ environments (within the range of expected Intergovernmental Panel on Climate Change, IPCC, predictions) have been shown to lose aural and olfactory capabilities (Munday et al. 2009b, Simpson et al. 2011), resulting in elevated predation risk when larvae become unaware of sounds and smells that would otherwise be avoided (Ferrari et al. 2011). Similarly, larval exposure to elevated pH could result in diminished preferences for physicochemical conditions, such as the outflow of freshwater into nearshore environments from flooding events (Smith \& Smith 1998), thought to serve as cues for re-entry into streams. As a consequence, climate-induced physicochemical changes may lead to higher larval mortality or lower recruitment, particularly when coupled with declining water inputs to streams that can dampen signals that guide re-entry of 'o'opu from marine environments.

Lesser known are the potential effects of climate change on ocean currents and circulation that could increase local recruitment and reduce the scale of connectivity among disjunct populations $\left(\mathrm{O}^{\prime}\right.$ Connor et al. 2007). The dependence of 'o'opu larval dispersal on ocean circulation patterns remains poorly understood (Radtke et al. 1988, Sorensen \& Hobson 2005), but large-scale currents are likely to mediate gene flow among stream populations within and among islands (Fitzsimons et al. 1990, Zink et al. 1996, Chubb et al. 1998). Studies of ocean circulation at spatial scales relevant to larval dispersal of amphidromous fishes (which generally have long LLD) would greatly improve understanding of weather- and climate-dependent marine dispersal (Munday et al. 2009a, Wilson et al. 2010). Biophysical modeling of larval transport, for example, could provide a predictive framework for determining the amount of variation in connectivity that is attributable to passive (i.e. ocean circulation, long-distance transport) and active dispersal (i.e. vertical migration, local retention) (Pous et al. 2010). This, in turn, would advance understanding of species responses to in-stream conditions relative to nearshore marine conditions and climate-driven shifts in open-ocean circulation patterns.

\section{ESCALATING ALTERATION AND LOSS OF IN-STREAM HABITAT}

The decline of native fishes has long served as an indicator of stream degradation arising from land conversion (i.e. urbanization) within and among watersheds (Senanayake \& Moyle 1982). As has been found in continental watersheds, native fish diversity and abundance in Hawaiian streams generally decline with alteration of land cover (Brasher 2003). Differential loss of 'o'opu reflects species-specific tolerances to changes in water quality, hydrology and habitat availability. Species that undergo inland migrations appear to be less tolerant of intensifying land use, as evidenced by the rarity of Lentipes concolor and Sicyopterus stimpsoni on Oahu (Maciolek 1977, Timbol et al. 1980, Fitzsimons et al. 1990, Higashi \& Yamamoto 1993, M. J. Blum et al. unpubl. data). Lower densities of Awaous guamensis-considered to be the most tolerant inland migrant - in forested watersheds across Oahu (M. J. Blum et al. unpubl. data) also suggest that effects of urbanization can extend well beyond the watersheds in which it occurs.

Intensifying watershed land use in Hawaii is accompanied by characteristic physical and chemical shifts in stream conditions that reduce habitat suitable for 'o'opu (Brasher 2003, Brasher \& Wolff 2004). Urbanization often leads to the removal of riparian vegetation, channelization and streambed stabilization. The resulting shallow, straight, concrete-lined channels are more favorable for flood control than for occupancy by native fishes. The absence of natural substrates can exclude 'o'opu that exhibit substrate preferences for feeding, predator avoidance and reproduction. Stream alterations are also likely to reduce base flow and amplify peak flow conditions. For fish larvae, these hydrological shifts have the potential to impede emigration following hatching and immigration of recruiting post-larvae. Adult gob- 
ies are also likely to suffer from altered stream flows and water temperatures (Brasher 2003). Cementlined urban streams on Oahu, for example, exhibit greater mean and maximum daily temperatures as well as greater daily temperature fluctuations relative to streams in forested watersheds (Brasher 2003). Such thermal changes may exceed the tolerances of temperature-sensitive species (Timbol \& Maciolek 1978, Shier 1998, Brasher 2003).

In many respects, urban streams subject resident species to hydrological and temperature regimes that are contemporary analogues of predicted climatedriven conditions. In addition to influencing the volume and periodicity of stream flow, climate warming is expected to alter the temperature of surface waters. As air temperatures rise, baseline water temperatures are expected to rise by 1 to $5^{\circ} \mathrm{C}$ over the coming century (Mohseni et al. 1999), although considerable regional variation is likely (Eaton \& Scheller 1996). As with physical modification of streams, elevated temperatures from climate warming can reduce available habitat for temperature-sensitive species. Physiological stress may occur as species are pushed to the limits of thermal physiological performance (Tewksbury et al. 2008), and progressive loss of local populations will become increasingly likely as more watersheds are subject to the combined influence of shifting land use and climate warming.

\section{PROMOTING THE SPREAD OF INVASIVE SPECIES}

Biological invasions are among the most significant threats to aquatic biodiversity worldwide (Leprieur et al. 2008). The diversity of non-native fish in Hawaiian streams is approximately an order of magnitude higher than native fish diversity (Devick 1991, Eldredge 1992, Brown et al. 1999, Yamamoto \& Tagawa 2000). Non-native freshwater fishes occur in nearly every watershed, having been intentionally introduced for mosquito control, recreational fishing, control of invasive plants, and as food sources. Exotic species have also been released from household aquaria. Non-native species can alter native communities through indirect and direct interactions. Nonnative catfish, for example, can increase stream siltation and turbidity as well as regulate the availability of nutrients essential for growth and reproduction (Vanni et al. 2002, Rowe 2007). Introduced game fish such as largemouth and smallmouth bass (Micropterus spp.) directly impact 'o'opu populations as predators on post-larvae and adults.
Poeciliids (e.g. Poecilia reticulata, Gambusia spp. and Xiphophorus spp.), widely introduced for mosquito control (or via the pet trade), may represent the greatest threat to 'o'opu. Poeciliids, also referred to as livebearers, are among the most common nonnative fish found in Hawaiian streams and rivers. Stream survey records from the Hawaii Division of Aquatic Resources indicate that at least $14 \%$ of the 283 streams containing 'o'opu also harbor poeciliid species. In addition to competing with 'o'opu for food resources (R. MacKenzie pers. comm.) and acting as a bridge for the transmission of non-native parasites to 'o'opu (Vincent \& Font 2003), poeciliids are also likely predators of 'o'opu at early life stages. 'O'opu larvae hatch and drift en masse just before and after sunset (Lindstrom 1998), which is concurrent with poeciliid surface feeding. Given the high densities and broad distributions of poeciliids in Hawaiian streams, predation on 'o'opu could depress larval production and recruitment throughout the archipelago. Livebearers have also been identified as a threat to other native species. Native damselfly Megalagrion nigrohamatum nigrolineatum populations, for example, have been significantly reduced where poeciliids are established (Englund 1999).

The transformation of flow and temperature regimes resulting from changes in land use and climate may favor non-native fish over 'o'opu in Hawaii. Many non-native stream-dwelling fishes thrive under intermittent flow and warm water conditions. Surveys of altered streams on Oahu, for example, have found that fish assemblages are largely composed of nonnative species with broad environmental tolerances (Norton et al. 1978, Timbol \& Maciolek 1978, Brasher et al. 2006, M. J. Blum et al. unpubl. data). Many of these streams are dominated by poeciliids that are highly tolerant of thermal stress (Hernández \& Bückle 2002) and hypoxia (Timmerman \& Chapman 2004). It is therefore likely that climate warming will act synergistically with stream habitat alteration to elevate invasion risk by creating conditions that favor nonnative over native species (Winder et al. 2011).

\section{CONSERVATION OF AMPHIDROMOUS FISHES}

Although all amphidromous fishes in Hawaii are at risk, status and protection differ among species. Currently, only Sicyopterus stimpsoni appears on the IUCN Red List of Threatened Species - as 'Near Threatened,' which is a risk category for taxa that are approaching a 'Vulnerable' condition yet do not qualify for 'Conservation Dependent' status (IUCN 
2011). Lentipes concolor was listed as 'Vulnerable' from 1986 to 1994, but following a re-assessment in 1996, the species was re-classified as 'Data Deficient' (IUCN 2011). The remaining 'o'opu species have no special conservation status according to the IUCN. Comprehensively documenting contemporary distributions and local population sizes will be necessary to evaluate whether current classifications are in need of updating.

Reconstructing trends in the distribution and abundance of 'o'opu would also help identify conservation and management priorities. The Hawaii Division of Aquatic Resources maintains a database that catalogues freshwater biota as well as watershed and land-use data (http://hawaii.gov/dlnr/dar/streams_ survey_data.html). The data set is an important archive of information on the presence of species in watersheds across the archipelago. To provide an example of how the archive can be used as a conservation tool, we evaluated variation in 'o'opu species richness in watersheds according to forest cover and agricultural land use conditions. Fig. 4 illustrates relationships between 'o'opu species richness and the percent of land within a watershed that is classified as agricultural-urban across the archipelago, based on point quadrat survey data in the archive. With few exceptions, more 'o'opu species are present in watersheds with a higher proportion of forested land cover, whereas fewer species occur in watersheds with more agricultural and urban development. Even though the native fish assemblage is naturally depauperate, these relationships are comparable to trends observed in continental fish assemblages (Scott 2006). With more detailed documentation of available survey data (e.g. date of collection), the archive could be used to reconstruct and assess more complex relationships. For example, it may be possible to disentangle the influence of land use from the influence of water diversions, and similarly, to determine whether the decline of native species corresponds to introductions of particular non-native species (Brasher et al. 2006). If regularly updated, the archive could also be used to characterize species responses to climate change, as has been done in the Grinnell Resurvey Project (Moritz et al. 2008).

Addressing recognized and emerging threats to 'o'opu across Hawaii requires gaining increased public support for conservation and restoration efforts. Removing recognized (e.g. bass) and likely non-native predators (e.g. poeciliids), for example, would likely be of great benefit to 'o'opu. Similarly, establishing minimum in-stream flow standards would reduce the risk of catastrophic loss of local



Fig. 4. Trends among the number of native amphidromous fish species ('o'opu) and percent of land within a watershed that is classified as agricultural-urban according to the Hawaii Watershed Atlas. Each dot represents a watershed. Data were obtained from The Hawaii Division of Aquatic Resources Watershed Atlas (http://www.hawaiiwatershed atlas.com/)

populations, while recognizing that growing human populations are placing greater demands on freshwater resources for residential and commercial use. Taking action to address priority conservation concerns therefore must be coupled with outreach and educational initiatives to enhance public awareness and appreciation of native freshwater species. Such approaches have proven successful for conservation of at-risk terrestrial fauna. Efforts to conserve native birds, for example, have led to massive campaigns to preserve habitat and to remove problematic nonnative species in Hawaii (e.g. rats).

Conservation efforts have generally been smallscale, local projects intended to demonstrate how preservation, stream restoration (including placement of structures enabling fish passage), non-native species removal and reintroductions can benefit 'o'opu. No doubt, scaling up these efforts will be challenging. Similarly, as has been proposed for conservation of other Indo-Pacific amphidromous fish faunas (Jenkins et al. 2009), ecosystem-based approaches targeting the preservation of forest cover and the prevention of non-native species introductions will also be challenging. Preservation of streams, for example, ideally should extend beyond headwaters (where most protected areas are now located) to encompass the full range of elevations within a watershed. Doing so, however, is neither cost effective nor is it likely to encompass coastal zones that have been heavily developed. Targeted approaches, such as protection of stream mouths to help ensure re-entry to watersheds, are an essential first step. Implementing novel approaches may also be required. For example, genetic control of sex 
ratios in non-native poeciliids could be an effective method for reducing predation of 'o'opu (Thresher et al. 2007, Thresher 2008).

Conservation of at-risk species and assemblages can sometimes be achieved through the protection of an endangered species that occupies the same habitat. Despite a lack of federal or state listing, protection granted to other freshwater organisms will likely benefit co-occurring 'o'opu populations. The damselfly Megalagrion nigrohamatum nigrolineatum, endemic to the island of Oahu, is currently being considered for listing as a federally endangered species (http://ecos.fws.gov/speciesProfile/profile/species Profile.action?spcode=I05U). Habitat loss, predation from introduced fishes, and competition with introduced insects restricts $M$. n. nigrolineatum to the upper reaches of 16 watersheds on Oahu (Flint et al. 2003, http://ecos.fws.gov/speciesProfile/profile/ speciesProfile.action?spcode=I05U). The restoration and protection of critical $M$. n. nigrolineatum habitat from development and diversion has the potential to benefit 'o'opu, especially if efforts are extended beyond currently occupied habitat to include critical habitat in other watersheds.

The maintenance of ocean-stream connectivity under conditions of declining freshwater inputs will likely prove to be the greatest challenge to conservation of amphidromous fish. Disruption of migratory pathways is a well-recognized threat to the survival of anadromous species, which has motivated costly actions by humans to ensure passage of the fish. Disruption of ocean-stream connectivity has yet to receive the same consideration for amphidromous species in Hawaii and elsewhere. Although state legislation has been passed in Hawaii (e.g. Chapter 176D, The Hawai'i Instream Use Protection Act of 1982; Chapter 174C, HRS, The State Water Code of 1987) requiring interim and permanent in-stream flow standards be set to protect, enhance and reestablish beneficial in-stream uses (i.e. native fish habitat) of water (Sakoda 2007), the adoption of interim and permanent in-stream flow standards has been highly contentious. This is partly because instream benefits are weighed against the economic impact of restricting non-stream uses. Similarly, interim standards predominantly have been set after deduction of flow from existing diversions. The Interim Instream Flow Standard adopted on 15 June 1988 for all streams on East Maui, for example, 'shall be that amount of water flowing in each stream on the effective date of this standard, and...under the stream conditions existing on the effective date of the standard' (http://hawaii.gov/dlnr/cwrm/regulations/ 13-169-44.pdf). Equally complicating, however, is the lack of available data on flow characteristics necessary to promote outgoing larval dispersal and reentry of post-larvae from the ocean to sustain resident populations. Not surprisingly, the commission tasked with setting in-stream flow standards must apply 'a methodology that recognizes the preliminary and incomplete nature of existing evidence' and therefore relies as much on policy considerations as on scientific knowledge (Sakoda 2007). Thus, a critical step forward in the adoption of biologically meaningful in-stream flow standards will be determining the hydrological conditions necessary to positively impact 'o'opu recruitment to breeding populations under current and future climate conditions. Understanding how 'o' opu perform under conditions analogous to predicted scenarios, for example, will help account for climate-driven changes in water quantity and quality. In the interim, the metapopulation dynamics of the amphidromous life cycle may be sufficient to prevent wholesale loss of species if robust populations (i.e. net-exporting) are able to supply immigrants to compromised populations via oceanic dispersal.

Acknowledgements. This work was funded by the US Department of Defense Strategic Environmental Research and Development Program (SERDP) as part of project RC1646.

\section{LITERATURE CITED}

Bailey HC, Miller LJ, Miller MJ, Dhaliwal BS (1995) Application of toxicity identification procedures to the echinoderm fertilization to identify toxicity of municipal effluent. Arch Environ Contam Toxicol 18:747-755

> Benstead JP, March JG, Pringle CM, Scatena FN (1999) Effects of a low-head dam and water abstraction on migratory tropical stream biota. Ecol Appl 9:656-668

Brasher AMD (1996) Monitoring the distribution and abundance of native gobies ('o'opu) in Waikolu and Pelekunu Streams on the island of Moloka'i. Cooperative National Park Resources Studies Unit Tech Rep 113, Hononulu, HI

Brasher AMD (1997) Habitat use by fish ('o'opu), snails (hihiwai), shrimp (opae) and prawns in two streams on the island of Moloka'i. Cooperative National Park Resources Studies Unit Tech Rep 116, Honolulu, HI

Brasher AMD (2003) Impacts of human disturbances on biotic communities in Hawaiian streams. Bioscience 53: 1052-1060

Brasher AMD, Wolff RH (2004) Relations between land use and organochlorine pesticides, $\mathrm{PCBs}$, and semi-volatile organic compounds in streambed sediment and fish on the Island of Oahu, Hawaii. Arch Environ Contam Toxicol 46:385-398

Brasher AMD, Luton CD, Goodbred SL, Wolff RH (2006) Invasion patterns along elevation and urbanization gradients in Hawaiian streams. Trans Am Fish Soc 135: 1109-1129 
Brown LR, Brasher AM, Harvey BC, Matthews M (1999) Success and failure of nonindigenous aquatic species in stream systems: case studies from California and Hawaii. In: Claudi R, Leach JH (eds) Nonindigenous freshwater organisms: vectors, biology, and impacts. Lewis Publishers, Boca Raton, FL, p 415-430

Carpenter SL, Fischer SG, Grimm NB, Kitchell JF (1992) Global climate change and freshwater ecosystems. Annu Rev Ecol Syst 23:119-139

Chu PS, Chen H (2005) Interannual and interdecadal rainfall variations in the Hawaiian Islands. J Clim 18:4796-4813

> Chubb AL, Zink RM, Fitzimons JM (1998) Patterns of mtDNA variation in Hawaiian freshwater fishes: the phylogeographic consequences of amphidromy. J Hered 89: 8-16

Corkum LD (2002) Discrimination among fish models by Hawaiian Eleotris sandwicensis (Eleotridae). Biotropica 34:584-588

Cowen RK, Paris CB, Srinivasan A (2006) Scaling of connectivity in marine populations. Science 311:522-527

> Delacroix P, Champeau A (1992) Ponte en eau douce de Sicyopterus lagocephalus (Pallas) poisson Gobiidae amphibionte des rivières de La Réunion. Hydroecol Appl 4:49-63

Devick WS (1991) Patterns of introductions of aquatic organisms to Hawaiian fresh waters. In: Devick WS (ed) New directions in research, management and conservation of Hawaiian freshwater stream ecosystems. Proc 1990 Symp Freshwater Stream Biology and Fisheries Management. Division of Land and Natural Resources, Division of Aquatic Resources, Honolulu, HI, p 189-213

Diaz HF, Chu PS, Eischeid JK (2005) Rainfall changes in Hawaii during the last century. 16th Conference on Climate Variability and Change, American Meteorological Society, Boston, MA

Eaton JG, Scheller RM (1996) Effects of climate warming on fish thermal habitat in streams of the United States. Limnol Oceanogr 41:1109-1115

Eldredge LG (1992) Unwanted strangers: an overview of animals introduced into Pacific islands. Pac Sci 46:384-386

- Englund RA (1999) The impacts of introduced poeciliid fish and Odonata on the endemic Megalagrion (Odonata) damselflies of Oahu Island, Hawaii. J Insect Conserv 3: 225-243

Englund RA, Filbert R (1997) Discovery of the native stream goby, Lentipes concolor, above Hawaii's highest waterfall Hi'ilawe falls. Bishop Mus Occas Pap 49:62-64

Erdman DS, Corujo-Flores IN, Gonzalez-Azar J, OrtizCarasquillo W (1984) Los peces de agua dulce de Puerto Rico. Departmento de Recursos Naturales, San Juan

> Ferrari MCO, Dixson DL, Munday PL, McCormick MI, Meekan MG, Sih A, Chivers DP (2011) Intrageneric variation in antipredator responses of coral reef fishes affected by ocean acidification: implications for climate change projections on marine communities. Glob Change Biol 17:2980-2986

Fitzsimons JM, Zink RM, Nishimoto RT (1990) Genetic variation in the Hawaiian stream goby, Lentipes concolor. Biochem Syst Ecol 18:81-83

Fitzsimons JM, Schoenfuss HL, Schoenfuss TC (1997) Significance of unimpeded flows in limiting the transmission of parasites from exotics to Hawaiian stream fishes. Micronesica 30:117-125

Fitzsimons JM, McRae MG, Nishimoto RT (2007) Behavioral ecology of indigenous stream fishes of Hawai'i. In: Even- huis L, Fitzsimons JM (eds) Biology of Hawaiian streams and estuaries. Bishop Mus Bull Cult Environ Stud 3:11-21

Flint OS, Englund RA, Kumashiro BR (2003) A reassessment and new state records of Trichoptera occurring in Hawaii with discussion on origins and potential ecological impacts. Bishop Mus Occas Pap 73:31-40

Gingerich SB, Wolff RH (2005) Effects of surface-water diversions on habitat availability for native macrofauna, northeast Maui, Hawaii. USGS Scientific Investigations Report, 2005-5213. USGS, Reston, VA

Golbuu Y, Wolanski E, Harrison P, Richmond RH, Victor S, Fabricius KE (2011) Effects of land-use change on characteristics and dynamics of watershed discharges in Babeldaob, Palau, Micronesia. J Mar Biol 2011:981273 doi:10.1155/2011/981273

Guswa AJ, Rhodes AL, Newell SE (2007) Importance of orographic precipitation to the water resources of Monteverde, Costa Rica. Adv Water Resour 30:2098-2112

Hernández RM, Bückle RLF (2002) Temperature tolerance polygon of Poecilia sphenops Valenciennes (Pisces: Poeciliidae). J Therm Biol 27:1-5

Higashi GR, Yamamoto MN (1993) Rediscovery of 'extinct' Lentipes concolor (Pisces: Gobiidae) on the island of Oahu, Hawaii. Pac Sci 47:115-117

> Hoegh-Guldberg O, Bruno J (2010) The impact of climate change on the world's marine ecosystems. Science 328: 1523-1528

> Holmquist JG, Schmidt-Gengenbach JM, Yoshioka BB (1998) High dams and marine-freshwater linkages: effects on native and introduced fauna in the Caribbean. Conserv Biol 12:621-630

Iida M, Watanabe S, Yamada Y, Lord C, Keith P, Tsukamoto K (2010) Survival and behavioral characteristics of amphidromous goby larvae of Sicyopterus japonicus (Tanaka, 1909) during their downstream migration. J Exp Mar Biol Ecol 383:17-22

IUCN (2011) IUCN Red List of Threatened Species. Version 2011.1, available at www.iucnredlist.org

Jenkins AP, Jupiter SD, Quaqua I, Atherton J (2009) The importance of ecosystem-based management for conserving aquatic migratory pathways on tropical high islands: a case study from Fiji. Aquat Conserv: Mar Freshw Ecosyst 20:224-238

Johansen JL, Jones GP (2011) Increasing ocean temperature reduces the metabolic performance and swimming ability of coral reef damselfishes. Glob Change Biol 17: 2971-2979

Keith P (2003) Biology and ecology of amphidromous Gobiidae in the Indo-Pacific and the Caribbean regions. J Fish Biol 63:831-847

Keith P, Lord C, Lorion J, Watanabe S, Tsukamoto K, Couloux A, Dettai A (2011) Phylogeny and biogeography of Sicydiinae (Teleostei: Gobiidae) inferred from mitochondrial and nuclear genes. Mar Biol 158:311-326

> Kinzie RA III (1988) Habitat utilization by Hawaiian stream fishes with reference to community structure in oceanic island streams. Environ Biol Fishes 22:179-192

Kinzie RA III, Ford JI, Yuen AR, Chow SJ (1984) Habitat utilization curves for native Hawaiian stream fish. Water Resources Research Center Special Report No. 6:20:84, University of Hawaii, Manoa, HI

Kinzie RA III, Ford JI, Yuen AR, Chow SJL (1986) Habitat modeling of Hawaiian streams. University of Hawaii Water Resources Research Center Tech Rep 171, University of Hawaii, Manoa, HI 
Leprieur F, Beauchard O, Blanchet S, Oberdorff T, Brosse S (2008) Fish invasions in the world's river systems: when natural processes are blurred by human activities. PLoS Biol 6:e28

Lettenmaier DP, Gan TY (1990) Hydrologic sensitivities of the Sacramento-San Joaquin river basin, California, to global warming. Water Resour Res 26:69-86

Lindstrom DP (1998) Reproduction, early development and larval transport dynamics of amphidromous Hawaiian gobioids. PhD thesis, University of Hawai'i, Honolulu, HI

Lindstrom DP, Blum MJ, Walter RP, Gagne RB, Gilliam JF (in press) Molecular and morphological evidence of distinct evolutionary lineages of Awaous guamensis in Hawai'i and Guam. Copeia

Lord C, Brun C, Hautecoeur M, Keith P (2010) Insights on endemism: comparison of the duration of the marine larval phase estimated by otolith microstructural analysis of three amphidromous Sicyopterus species (Gobioidei: Sicydiinae) from Vanuatu and New Caledonia. Ecol Freshw Fish 19:26-38

Maciolek JA (1977) Taxonomic status, biology, and distribution of Hawaiian Lentipes, a diadromous goby. Pac Sci 31:355-362

> MacKenzie RA (2008) Impacts of riparian forest removal on Palauan streams. Biotropica 40:666-675

McDowall RM (1997) Is there such a thing as amphidromy? Micronesica 30:3-14

McDowall RM (2003) Hawaiian biogeography and the islands' freshwater fish fauna. J Biogeogr 30:703-710

McDowall RM (2004) Ancestry and amphidromy in island freshwater fish faunas. Fish Fish 5:75-85

> McDowall RM (2010) Why be amphidromous: expatrial dispersal and the place of source and sink population dynamics? Rev Fish Biol Fish 20:87-100

- McJannet DL, Wallace JS, Reddell P (2007) Precipitation interception in Australian tropical rainforests: II. Altitudinal gradients of cloud interception, stemflow, throughfall and interception. Hydrol Processes 21:1703-1718

> McKaye KR, Weiland DJ, Lim TM (1979) Comments on the breeding biology of Gobiomorus dormitor (Osteichthyes: Eleotridae) and the advantage of schooling behavior to its fry. Copeia 1979:542-544

McRae MG (2001) Microhabitat use in an assemblage of native and introduced stream fishes in Wailoa Stream, Island of Hawaii. MS thesis, Louisiana State University, Baton Rouge, LA

> Meisner JD, Shuter BJ (1992) Assessing potential effects of global climate change on tropical freshwater fishes. GeoJournal 28:21-27

> Michel C, Hicks BJ, Stölting KN, Clarke AC and others (2008) Distinct migratory and non-migratory ecotypes of an endemic New Zealand eleotrid (Gobiomorphus cotidianus) - implications for incipient speciation in island freshwater fish species. BMC Evol Biol 8:49

> Mohseni O, Erickson TR, Stefan HG (1999) Sensitivity of stream temperatures in the United States to air temperatures projected under a global warming scenario. Water Resour Res 35:3723-3733

Moritz C, Patton JL, Conroy CJ, Parra JL, White GC, Beissinger SR (2008) Impact of a century of climate change on small-mammal communities in Yosemite National Park, USA. Science 322:261-264

Munday PL, Leis JM, Lough JM, Paris CB, Kingsford MJ, Berumen ML, Lambrechts J (2009a) Climate change and coral reef connectivity. Coral Reefs 28:379-395

Munday PL, Dixson DL, Donelson JM, Jones GP, Pratchett MS, Devitsina GV, Doving KB (2009b) Ocean acidification impairs olfactory discrimination and homing ability of a marine fish. Proc Natl Acad Sci USA 106:1848-1852

Murphy CA, Cowen JA Jr (2007) Production, marine larval retention or dispersal, and recruitment of amphidromous Hawaiian gobioids: issues and implications. In: Evenhuis L, Fitzsimons JM (eds) Biology of Hawaiian streams and estuaries. Bishop Mus Bull Cult Environ Stud 3:63-74

Norton S, Timbol AS, Parrish JD (1978) Stream channel modification in Hawaii, Part B: effect of channelization on the distribution and abundance of fauna in selected streams. FWS/OBS-78/17. US Fish and Wildlife Service, National Stream Alteration Team, Columbia, MO

O'Connor MI, Bruno JF, Gaines SD, Halpern BS, Lester SE, Kinlan BP, Weiss JM (2007) Temperature control of larval dispersal and the implications for marine ecology, evolution and conservation. Proc Natl Acad Sci USA 104: 1266-1271

Oki DS (2004) Trends in streamflow characteristics at longterm gaging stations, Hawaii. USGS Scientific investigations report 2004-5080, USGS, Reston, VA

Parham JE (2002) Spatial models of Hawaiian streams and stream fish habitats. PhD thesis, Louisiana State University, Baton Rouge, LA

Parrish JD, Maciolek JA, Timbol AS, Hathaway CB Jr, Norton SE (1978) Stream channel modification in Hawaii, Part D: summary report. US Fish and Wildlife Service, National Stream Alteration Team FWS/OBS-78/19, Columbia, MO

> Pous S, Feunteun E, Ellien C (2010) Investigation of tropical eel spawning area in the south-western Indian Ocean: influence of the oceanic circulation. Prog Oceanogr 86: 396-413

Puritz JB, Toonen RJ (2011) Coastal pollution limits pelagic larval dispersal. Nat Commun 2:226

> Radtke RL, Kinzie RA (1996) Evidence of a marine larval stage in endemic Hawaiian stream gobies from isolated high-elevation localities. Trans Am Fish Soc 125:613-621

Radtke L, Kinzie RA, Folsom, SD (1988) Age at recruitment of Hawaiian freshwater gobies. Environ Biol Fish 23: 205-213

Radtke RL, Kinzie RA, Shafer DJ (2001) Temporal and spatial variation in length of larval life and size at settlement of the Hawaiian amphidromous goby Lentipes concolor. J Fish Biol 59:928-938

> Rowe DK (2007) Exotic fish introductions and the decline of water clarity in small North Island, New Zealand lakes: a multi-species problem. Hydrobiologia 583:345-358

Sakoda ET (2007) Setting instream flow standards for Hawaiian streams - the role of science. In: Evenhuis L, Fitzsimons JM (eds) Biology of Hawaiian streams and estuaries. Bishop Mus Bull Cult Environ Stud 3:293-304

> Scott MC (2006) Winners and losers among stream fishes in relation to land use legacies and urban development in the southeastern US. Biol Conserv 127:301-309

Senanayake FR, Moyle PB (1982) Conservation of freshwater fishes of Sri Lanka. Biol Conserv 22:181-195

Shier AD (1998) The effect of channelization and clearing of riparian vegetation on temperature of two streams on the island of Oahu. MS thesis, University of Hawai'i, Honolulu, HI

Simpson SD, Munday PL, Wittenrich ML, Manassa R, Dixson DL, Gagliano M, Yan HY (2011) Ocean acidification 
erodes crucial auditory behaviour in a marine fish. Biol Lett 7:917-920

Smith RFJ, Smith MJ (1998) Rapid acquisition of directional preferences by migratory juveniles of two amphidromous Hawaiian gobies, Awaous guamensis and Sicyopterus stimpsoni. Environ Biol Fishes 53:275-282

Sorensen PW, Hobson KA (2005) Stable isotope analysis of amphidromous Hawaiian gobies suggests their larvae spend a substantial period of time in freshwater river plumes. Environ Biol Fishes 74:31-42

Sponaugle S, Pinkard DL (2004) Impact of variable larval environments on natural larval growth and recruitment of the reef fish Thalassoma bifasciatum. J Fish Biol 64: 34-54

Sponaugle S, Grorud-Colvert K, Pinkard D (2006) Temperature-mediated variation in early life history traits and recruitment success of the coral reef fish Thalassoma bifasciatum in the Florida Keys. Mar Ecol Prog Ser 308:1-15

Still CJ, Foster PN, Schneider SH (1999) Simulating the effects of climate change on tropical montane cloud forests. Nature 398:608-610

Sutherland RA (2000) Bed sediment-associated trace metals in an urban stream, Oahu, Hawaii. Environ Geol 39: 611-627

Takahashi M, Giambelluca TW, Mudd RG, DeLay JK, Nellet MA, Asner GP (2011) Rainfall partitioning and cloud water interception in native forest and native forest in Hawai'i Volcanoes National Park. Hydrol Processes 25: 448-464

Tewksbury JJ, Huey RB, Deutsch CA (2008) Putting the heat on tropical animals. Science 320:1296-1297

Thresher RE (2008) Autocidal technology for the control of invasive fish. Fisheries 33:114-121

Thresher RE, Grewe P, Patil J, Hinds L (2007) Genetic control of sex ratio in animal populations. Australian Patent 2001291520, Commonwealth Scientific and Industrial Research Organisation, Hobart

Timbol AS, Maciolek JA (1978) Stream channel modification in Hawaii, Part A: statewide inventory of streams: habitat factors and associated biota. US Fish and Wildlife Service, Office of Biological Services Report FWS/OBS78/16, Columbia, MO

Timbol AS, Sutter AJ, Parrish JD (1980) Distribution, relative

Editorial responsibility: Steven Cooke,

Ottawa, Ontario, Canada abundance, and stream environment of Lentipes concolor (Gill 1860), and associated fauna in Hawaiian streams. University of Hawaii at Manoa, Water Resources Research Center. Cooperative Report no. 5, Honolulu, HI

Timm O, Diaz HF (2009) Synoptic-statistical approach to regional downscaling of IPCC twenty-first century climate projections: seasonal rainfall over the Hawaiian Islands. J Clim 22:4261-4280

> Timmerman CM, Chapman LJ (2004) Hypoxia and interdemic variation in Poecilia latipinna. J Fish Biol 65: 635-665

US Census Bureau (2010) Resident population data. US Census Bureau, Washington, DC, available at http: //2010.census.gov/2010census/data/apportionment-pop -text.php

> Vanni MJ, Flecker AS, Hood JM, Headworth JL (2002) Stoichiometry of nutrient recycling by vertebrates in a tropical stream: linking species identity and ecosystem processes. Ecol Lett 5:285-293

Vincent AG, Font WF (2003) Seasonal and yearly population dynamics of two exotic helminthes, Camallanus cotti (nematode) and Bothriocephalus acheilognathi (Cestoda), parasitizing exotic fishes in Waianu stream, O'ahu, Hawaii. J Parasitol 89:756-760

Watson RE (1991) A provisional review of the genus Stenogobius with descriptions of a new subgenus and thirteen new species (Pisces: Teleostei: Gobiidae). Rec West Aust Mus 15:627-710

Wilson SK, Adjeroud M, Bellwood DR, Berumen ML and others (2010) Crucial knowledge gaps in current understanding of climate change impacts on coral reef fishes. J Exp Biol 213:894-900

Winder M, Jassby AD, MacNally R (2011) Synergies between climate anomalies and hydrological modifications facilitate estuarine biotic invasions. Ecol Lett 14: 749-757

Yamamoto MN, Tagawa AW (2000) Hawaii's native and exotic freshwater animals. Mutual Publishing, Honolulu, HI

Zink RM, Fitzsimons JM, Dittman DL, Reynolds DR, Nishimoto RT (1996) Evolutionary genetics of Hawaiian freshwater fish. Copeia 1996:330-335

Submitted: August 8, 2011; Accepted: December 4, 2011

Proofs received from author(s): March 6, 2012 